\title{
Cigarette Smoking and Attitudes Concerning Its Control among Healthcare Workers in Enugu, South-East, Nigeria
}

\author{
I. B. Omotowo ${ }^{1 *}$, E. O. Ndibuagu ${ }^{2}$, U. Ezeoke ${ }^{1}$ \\ ${ }^{1}$ Department of Community Medicine, College of Medicine, University of Nigeria, Enugu Campus, Enugu, Nigeria \\ ${ }^{2}$ Department of Community Medicine \& Primary Health Care, Enugu State University College of Medicine, \\ Enugu, Nigeria \\ Email: "babatunde.omotowo@unn.edu.ng
}

Received 5 May 2016; accepted 9 August 2016; published 12 August 2016

Copyright (C) 2016 by authors and Scientific Research Publishing Inc.

This work is licensed under the Creative Commons Attribution International License (CC BY). http://creativecommons.org/licenses/by/4.0/

(c) (i) Open Access

\begin{abstract}
Introduction: Cigarette smoking is an established risk factor for many diseases, and according to World Health Organization, health care workers can influence positively or negatively the smoking habits of the community. Objective: The purpose of the study was to investigate the prevalence of cigarette smoking and attitudes regarding its control among healthcare workers in Enugu, South-East Nigeria. Methods: This cross sectional study was conducted among 369 healthcare providers randomly selected in primary, secondary and tertiary health facilities. Data were collected using a self reported questionnaire on cigarette smoking, and were analysed using SPSS Version 21, and statistical significance of association between variables was assessed using chi-square test at $p<0.05$. Ethical clearance from University of Nigeria Teaching Hospital, Enugu and informed written consent was obtained from the participants. Results: Overall, 369 respondents returned the completed questionnaires. $54.2 \%$ were males, $75.9 \%$ were aged between 20 to 40 years, while their mean age was $27.5 \pm 6.2$ years. Overall life time prevalence of smoking among healthcare workers was $21.1 \%$ with (95\% confidence interval $17.3-25.6)$, currently smoking was $6.5 \%$ with (95\% confidence interval 5.8 - 7.4), while life time prevalence among physicians was $31.7 \%$ with (95\% ci 28.8 - 33.6). The highest smoking rate was among the internists $72.7 \%$ in the physicians group. More smokers significantly agreed that the followings should be banned: cigarette sales $\left(\mathrm{X}^{2}\right.$ $=22.134, \mathrm{df}=6, \mathrm{P}=0.003)$, advertising cigarettes $\left(\mathrm{X}^{2}=42.532, \mathrm{df}=28, \mathrm{P}=0.040\right)$, cigarettes smoking in restaurants $\left(X^{2}=42.560, d f=20, P=0.001\right)$, and smoking in all enclosed places $\left(X^{2}=\right.$ 33.257, $\mathrm{df}=20, \mathrm{P}=\mathbf{0 . 0 2 5}$ ), but not statistically significant for health professionals to serve as role models $\left(X^{2}=24.420, \mathrm{df}=8, \mathrm{P}=0.086\right)$. Conclusion: Our results showed high percentage of cigarette smoking among healthcare providers. Smoking cessation programs should be introduced among healthcare providers.
\end{abstract}

\footnotetext{
${ }^{*}$ Corresponding author.
} 
Keywords

Prevalence, Smoking, Healthcare Workers

\section{Introduction}

Smoking is an established risk factor for many diseases and reported to be one of the most important public health problems worldwide. [1] It has been clearly shown that cigarette smoking is causal factor in the development of many serious medical problems, most notably cardiovascular disease, cerebrovascular disease, lung cancer, and chronic obstructive airways disease, as well as tumours of the mouth, larynx, oesophagus, lip, and bladder. Other neoplastic and respiratory causes of death, newborn and infant deaths due to maternal smoking, cigarette-caused residential fires, and passive smoking deaths from lung cancer are also substantial components of tobacco related mortality [1].

Smoking can be seen as the unmet challenge confronting all those with responsibilities for personal and public health [2]. The challenge is particularly great as the pleasure of smoking gives instant satisfaction. Shortterm effects are enjoyed but long term results are obvious years after exposure. The long term debt is always catastrophic for the individual and places great demands on society in which the smokers live [3]. Tobacco kills over five million people every year, and accounts for $10 \%$ of all adult mortality. If the current trends continue, tobacco will be responsible for seven million by 2020 and more than eight million deaths per year by 2030 [4]. Also, for every death caused by smoking, approximately 20 smokers are suffering from a smoking related disease. About $80 \%$ of the 1.1 billion smokers in the world are living in developing countries where control measures are reported to be weak [5] [6]. A marginal yearly increase of 3\% in cigarette smoking has been reported for developing countries [7]. It is also reported that smoking prevalence is increasing in Nigeria [8] [9].

Several studies conducted for 20 years in some developed countries such as France [10] [11], Italy [12] [13], and Japan [14] [15] have consistently documented smoking rates in excess of $20 \%$. High prevalence is also reported among doctors in some developing countries. However, substantial progress has been made in many industrialized countries in reducing smoking prevalence among doctors [16].

Healthcare providers play a key role in the prevention of tobacco smoking as well as counselling patients to stop smoking [17]. The physician is particularly in a leading position to help patients to stop smoking because of the high rate of contact with the general public [18]. The efforts can reduce the smoking prevalence, mortality and morbidity from cigarette related diseases [18] [19]. Physicians can also reduce the enormous toll of cigarette smoking by acting at the public health and public policy levels [20]. Also, family physicians and paediatricians can play a key role in informing young people and their families about the addictive nature and other harmful effects of cigarette smoking [21]. Generally, doctors and nurses have authoritative power and are regarded as reliable and knowledgeable sources of health information [21]. It is estimated that about $70 \%$ of smokers see physicians each year with opportunity to influence smoking behaviour. Also, medical advice to quit smoking can lead to one year abstinence rates of up to $5 \%$ - 10\% [22]. Nevertheless, doctor is not taking full advantage of this opportunity to identify smokers and provide stop smoking advice in their routine work with patients [23]. Smoking among health professionals acts as a setback in the campaign to reduce smoking, because most patients consider their healthcare providers as their most trusted source of knowledge and guidance on health matters [20]. High smoking rates among doctors persist in several industrialised countries, and may represent the norm in developing countries [16] [24].

Knowledge of the prevalence of smoking among doctors is useful for at least two reasons. First, the information may indicate likelihood of success of population based anti-tobacco campaigns. Secondly, the prevalence of smoking among doctors may reflect the maturity of the smoking epidemic in a particular country [16] [25].

Generally, healthcare workers are highly respected in their communities. They are responsible for primary health care and education for tobacco related issues, as well as role models on health matters in the community. There have been reports on the smoking habits of physicians in South-East Nigeria, but there is a dearth of information to be best of our knowledge about the prevalence of smoking among healthcare workers, and their attitudes towards the control. We therefore conducted a cross-sectional study on prevalence of cigarette smoking and attitudes towards its control in Enugu metropolis. 


\section{Materials and Methods}

\subsection{Study Area}

The study was conducted among randomly selected healthcare workers in primary, secondary and tertiary health facilities in Enugu metropolis. Enugu metropolis is the capital of old Eastern region, and current Enugu state in south-east, Nigeria, with estimated population of 722,664 people. The metropolis has three Local Government Areas, which are Enugu east, Enugu south and Enugu north. There are four tertiary, 14 secondary, and 12 primary health facilities in Enugu metropolis. It is largely inhabited by Igbo people, and pockets of other tribes such as Hausa, Yoruba etc. The predominant economic activities of the people are commerce, agriculture and civil service.

\subsection{Study Design and Sampling Technique}

The study was cross-sectional in design, and a total of 430 healthcare workers were randomly selected. Two health facilities were randomly selected each from primary, secondary and tertiary levels. Facilities selected are University of Nigeria Teaching hospital, Enugu State University Teaching Hospital, Eastern Nigeria Medical Center, Mother of Christ Specialists Hospital, Cottage Health Centre Ibagwa, and Health Centre Abakpa-Nike. A total of 145 doctors, 101 nurses, 27 pharmacists, and 96 other health workers were selected for the study.

\subsection{Data Collection}

Data were collected using self-administered structured questionnaires designed to collect information on demographic characteristics, personal smoking habits, knowledge on the hazards of cigarette smoking, and attitudes on measures to control smoking.

\subsection{Inclusion Criteria}

All randomly selected health workers of University of Nigeria Teaching Hospital, Enugu, till the sample size of the categories of the health workers are achieved.

\subsection{Exclusion Criteria}

Health workers that are not staff of University of Nigeria Teaching Hospital, Enugu, and casual workers of the hospital.

\subsection{Ethical Approval}

Ethical approval was obtained from Health Research Ethics Committee of University of Nigeria Teaching Hospital (UNTH), Enugu. Approval was obtained from heads of other facilities used for the study, and all the respondents gave informed written consent. The participants were assured of confidentiality.

\subsection{Data Analysis}

Data collected was analysed using SPSS version 17 (SPSS Inc., Chicago, Illinois, USA) and differences in proportion between smokers and non-smokers were analysed using a chi-square test at $\mathrm{p}<0.05$ taken as level of significance.

\section{Results}

\subsection{Socio-Demographic Characteristics of the Study Participants}

A total of 369 out of 430 respondents returned their questionnaires giving a response rate of $85.8 \%$. The calculated minimum sample size was 360 , we added $20 \%$ because of attrition, so no further recruitment of participants when 369 returned their questionnaires.

The demographic characteristics of the health care workers are shown in Table 1. Majority of the participants are male $54.2 \%$, while $53.7 \%$ were married. 
Table 1. Socio-demographic characteristics of the health workers.

\begin{tabular}{|c|c|c|c|}
\hline Variables & Category & Frequency & Percent \\
\hline \multirow{2}{*}{ SEX } & Male & 200 & 54.2 \\
\hline & Female & 169 & 45.8 \\
\hline \multirow{3}{*}{ Age Grp (Years) } & $<20$ & 4 & 1.1 \\
\hline & $20-40$ & 280 & 75.9 \\
\hline & $>40$ & 85 & 23.0 \\
\hline \multirow{4}{*}{ Marital Status } & Single & 119 & 32.2 \\
\hline & Married & 198 & 53.7 \\
\hline & Divorced & 20 & 5.4 \\
\hline & Widowed & 32 & 8.7 \\
\hline \multirow{4}{*}{ Tribe } & Igbo & 279 & 75.6 \\
\hline & Yoruba & 42 & 11.4 \\
\hline & Hausa & 31 & 8.4 \\
\hline & Others & 17 & 4.6 \\
\hline \multirow{3}{*}{ Religion } & Christian & 338 & 91.6 \\
\hline & Islam & 24 & 6.5 \\
\hline & Traditional & 7 & 1.9 \\
\hline \multirow{6}{*}{ Years of Practice } & $<1$ & 75 & 20.3 \\
\hline & $1-5$ & 38 & 10.3 \\
\hline & $>5-10$ & 49 & 13.4 \\
\hline & $>10-15$ & 195 & 52.8 \\
\hline & $>15-20$ & 9 & 2.4 \\
\hline & $>20$ & 3 & 0.8 \\
\hline
\end{tabular}

\subsection{Categories of Health Workers in the Facilities}

Table 2 shows that physicians were 39.3\%, Nurses 27.4\%, pharmacists 7.3\%, Lab scientists/technologists $11.9 \%$, while others are $14.1 \%$. Majority of health workers are in the tertiary facilities

\subsection{Physicians Professional Hierarchy}

Interns, resident/medical officers, consultants and professors were 49\%, 33.8\%, 14.55\% and 2.7\% respectively Table 3.

\subsection{Knowledge of Participants on Harmful Effects of Cigarette Smoking}

Table 4 reveals that majority believed smoking can cause lung cancer 79.4\%, while other cancers, cardiovascular diseases, and respiratory diseases are $8.7 \%, 3.5 \%$ and $2.2 \%$ respectively

\subsection{Prevalence and Patterns of Cigarette Smoking among Health Workers}

Table 5 shows that overall life prevalence of cigarette smoking among all health workers was 21.1\% (CI 17.2 25.6), while it was 31.7\% (CI 28.8 - 33.6), 14.8\% (CI 16.4 - 27.9), and 9.9\% (22.8 - 31.7), among physicians, 
Table 2. Categories of health workers in the facilities.

\begin{tabular}{|c|c|c|c|c|c|c|c|c|}
\hline \multirow{2}{*}{ Category } & \multicolumn{2}{|c|}{ Tertiary } & \multicolumn{2}{|c|}{ Secondary } & \multicolumn{2}{|c|}{ Primary } & \multicolumn{2}{|c|}{ Total } \\
\hline & $\mathrm{N}$ & $\%$ & $\mathrm{~N}$ & $\%$ & $\mathrm{~N}$ & $\%$ & $\mathrm{~N}$ & $\%$ \\
\hline Physicians & 98 & 67.6 & 43 & 29.7 & 4 & 2.7 & 145 & 39.3 \\
\hline Nurses & 46 & 45.5 & 30 & 29.7 & 25 & 24.8 & 101 & 27.4 \\
\hline Pharmacists & 17 & 63.0 & 10 & 37.0 & 0 & 0 & 27 & 7.3 \\
\hline Med Lab Scientist/technologists & 25 & 56.8 & 15 & 34.1 & 4 & 9.1 & 44 & 11.9 \\
\hline Others & 17 & 32.7 & 20 & 38.5 & 15 & 28.8 & 52 & 14.1 \\
\hline
\end{tabular}

Table 3. Physicians professional hierarchy.

\begin{tabular}{ccc}
\hline Professional Hierarchy & Frequency & Percent \\
\hline Interns & 71 & 49.0 \\
Resident/Medical Officers & 49 & 33.8 \\
Consultant & 21 & 14.5 \\
Professor & 4 & 2.7 \\
Total & 145 & 100 \\
\hline
\end{tabular}

Table 4. Knowledge of participants on harmful effects of cigarette smoking.

\begin{tabular}{ccc}
\hline Harmful effects & Frequency & Percent \\
\hline Lung cancer & 293 & 79.4 \\
Other cancers & 32 & 8.7 \\
Cardiovascular diseases & 13 & 3.5 \\
Respiratory diseases & 8 & 2.2 \\
Ectopic pregnancy & 7 & 1.9 \\
Addiction & 5 & 1.4 \\
Infertility & 5 & 1.4 \\
Diabetes & 4 & 1.0 \\
Others & 2 & 0.5 \\
\hline
\end{tabular}

pharmacists and nurses respectively. Currently smoking prevalence among all health workers was $6.5 \%$ (5.8 7.4), while pharmacists, physicians, and nurses are 11.1\% (CI 7.6 - 10.9), 7.6\% (6.7 - 8.4) and $4 \%$ (9.8 - 11.8) respectively.

Among the physicians, currently smoking was highest among the interns $6.3 \%$ (CI 26.7 - 34.5), while consultants, resident/medical officers, and professors are 4.8\% (CI 18.4 - 22.7), 4.1\% (CI 33.6 - 41.8), and 0\% (CI 16.9 - 24.6) respectively.

\subsection{Reasons for Stopping Cigarette Smoking among Health Workers}

Table 6 shows that their profession 33.3\% was the major reason they stopped smoking, while other reasons such as knowledge of the health hazards, advice from colleagues, and to discourage other smokers are $22.2 \%, 16.7 \%$, and $12.9 \%$ respectively. 
Table 5. Prevalence and patterns of cigarette smoking among health workers.

\begin{tabular}{|c|c|c|c|c|c|c|c|}
\hline \multirow{3}{*}{ Variables } & \multirow{3}{*}{ Category } & \multicolumn{4}{|c|}{ Responses } & \multirow{3}{*}{ Total } & \multirow{3}{*}{$\begin{array}{l}\text { 95\% Confidence } \\
\text { Interval (CI) }\end{array}$} \\
\hline & & \multicolumn{2}{|c|}{ Yes } & \multicolumn{2}{|c|}{ No } & & \\
\hline & & $\mathrm{N}$ & $\%$ & $\mathrm{~N}$ & $\%$ & & \\
\hline \multirow{5}{*}{$\begin{array}{c}\text { Ever smoked } \\
\text { cigarette (overall } \\
\text { life prevalence) }\end{array}$} & All health workers & 78 & 21.1 & 291 & 78.9 & 369 & $17.3-25.6$ \\
\hline & Physicians & 46 & 31.7 & 99 & 68.3 & 145 & $28.8-33.6$ \\
\hline & Nurses & 10 & 9.9 & 91 & 90.1 & 101 & $22.8-31.7$ \\
\hline & Pharmacists & 4 & 14.8 & 23 & 85.2 & 27 & $16.4-27.9$ \\
\hline & Others & 18 & 18.8 & 78 & 81.2 & 96 & $19.4-26.8$ \\
\hline \multirow{5}{*}{ Currently smoking } & All health workers & 24 & 6.5 & 345 & 93.5 & 369 & $5.8-7.4$ \\
\hline & Physicians & 11 & 7.6 & 134 & 92.4 & 145 & $6.7-8.4$ \\
\hline & Nurses & 4 & 4.0 & 97 & 96.0 & 101 & $9.8-11.8$ \\
\hline & Pharmacists & 3 & 11.1 & 24 & 88.9 & 27 & $7.6-10.9$ \\
\hline & Others & 6 & 6.3 & 90 & 93.7 & 96 & $12.4-14.6$ \\
\hline \multirow{4}{*}{$\begin{array}{l}\text { Currently smoking } \\
\text { among physicians }\end{array}$} & Interns & 8 & 11.3 & 63 & 88.7 & 71 & $26.7-34.5$ \\
\hline & Resident/Med Officers & 2 & 4.1 & 47 & 95.9 & 49 & $33.6-41.8$ \\
\hline & Consultant & 1 & 4.8 & 20 & 95.2 & 21 & $18.4-22.7$ \\
\hline & Professor & 0 & 0 & 4 & 100 & 4 & $16.9-24.6$ \\
\hline \multirow{3}{*}{$\begin{array}{l}\text { Quantity of sticks } \\
\text { smoked per day }\end{array}$} & $1-5$ & 335 & 90.8 & - & - & - & \\
\hline & $6-10$ & 32 & 8.7 & - & - & - & \\
\hline & $>10$ & 2 & 0.5 & - & - & - & \\
\hline
\end{tabular}

Table 6. Reasons for stopping cigarette smoking among health workers.

\begin{tabular}{ccc}
\hline Reasons & Frequency & Percent \\
\hline Knowledge of health hazards & 12 & 22.2 \\
Advice from Colleagues and friends & 9 & 16.7 \\
To discourage other smokers & 7 & 12.9 \\
Warning by manufactures & 2 & 3.7 \\
Because of my profession & 18 & 33.3 \\
Because of the family & 6 & 11.2 \\
Total & 54 & 100 \\
\hline
\end{tabular}

\subsection{Attitudes of Respondents towards Cigarette Smoking among Health Workers}

Table 7 shows that majority of non smokers $68 \%$ wanted cigarettes to be banned while it was $51.3 \%$ among smokers $\left(\mathrm{X}^{2}=22.134, \mathrm{P}=0.003\right) .70 .5 \%$ of smokers wanted health professionals to routinely advise their patients who smoke to quit, while it was $80.4 \%$ among non smokers $\left(X^{2}=20.192, P=0.040\right)$ Majority of smokers $78.2 \%$ and non smokers $90 \%$ wanted health professionals to have a role in giving advice or information about smoking cessation to patients $\left(\mathrm{X}^{2}=21.352, \mathrm{P}=0.069\right)$. Only 58.9\% among smokers agreed that all health care providers should not smoke while it was $97.3 \%$ among non smokers $\left(\mathrm{X}^{2}=4.642, \mathrm{P}=0.052\right)$. 
Table 7. Attitudes of respondents towards cigarette smoking.

\begin{tabular}{|c|c|c|c|c|c|c|c|c|c|c|c|}
\hline \multirow{3}{*}{ Variables } & \multicolumn{4}{|c|}{ Smokers } & \multicolumn{4}{|c|}{ Non-smokers } & \multirow{3}{*}{ Total } & \multirow{3}{*}{$\begin{array}{l}\text { Chisquare } \\
\mathrm{X}^{2}\end{array}$} & \multirow{3}{*}{$\begin{array}{c}\text { P-value } \\
\text { P }\end{array}$} \\
\hline & \multicolumn{2}{|c|}{ Yes } & \multicolumn{2}{|c|}{ No } & \multicolumn{2}{|c|}{ Yes } & \multicolumn{2}{|c|}{ No } & & & \\
\hline & $\mathrm{N}$ & $\%$ & $\mathrm{~N}$ & $\%$ & $\mathrm{~N}$ & $\%$ & $\mathrm{~N}$ & $\%$ & & & \\
\hline Should cigarettes sales be banned? & 40 & 51.3 & 38 & 48.7 & 198 & 68.0 & 93 & 32.0 & 369 & 22.134 & 0.003 \\
\hline Should advertising cigarettes be banned? & 54 & 69.2 & 24 & 31.8 & 154 & 52.9 & 137 & 47.1 & 369 & 42.532 & 0.040 \\
\hline $\begin{array}{l}\text { Should health professionals routinely } \\
\text { advise their patients who smoke to } \\
\text { quit smoking? }\end{array}$ & 55 & 70.5 & 23 & 29.5 & 234 & 80.4 & 57 & 19.6 & 369 & 20.192 & 0.064 \\
\hline $\begin{array}{c}\text { Should health professionals have a role } \\
\text { in giving advice or information about } \\
\text { smoking cessation to patients? }\end{array}$ & 61 & 78.2 & 17 & 21.8 & 262 & 90.0 & 29 & 10.0 & 369 & 21.352 & 0.069 \\
\hline $\begin{array}{l}\text { Do health professionals } \\
\text { serve as role models? }\end{array}$ & 37 & 47.4 & 41 & 52.6 & 245 & 84.2 & 46 & 15.8 & 369 & 24.420 & 0.086 \\
\hline $\begin{array}{l}\text { Should smoking be prohibited } \\
\text { in all health facilities? }\end{array}$ & 70 & 89.7 & 8 & 10.3 & 282 & 96.9 & 9 & 3.1 & 369 & 23.890 & 0.079 \\
\hline $\begin{array}{l}\text { Do you agree that all health care } \\
\text { providers should not smoke? }\end{array}$ & 46 & 58.9 & 32 & 41.1 & 283 & 97.3 & 8 & 2.7 & 369 & 4.642 & 0.052 \\
\hline $\begin{array}{l}\text { Should smoking be banned in all } \\
\text { enclosed places? }\end{array}$ & 72 & 92.3 & 6 & 7.7 & 288 & 98.9 & 3 & 1.1 & 369 & 33.257 & 0.025 \\
\hline $\begin{array}{l}\text { Should smoking be banned } \\
\text { in restaurants? }\end{array}$ & 69 & 88.5 & 9 & 11.5 & 286 & 98.3 & 5 & 1.7 & 369 & 42.560 & 0.001 \\
\hline $\begin{array}{l}\text { Should health professionals be trained } \\
\text { in smoking cessation techniques? }\end{array}$ & 62 & 79.5 & 16 & 20.5 & 215 & 73.9 & 76 & 26.1 & 369 & 43.784 & 0.084 \\
\hline
\end{tabular}

Among smokers, $79.5 \%$ agreed that health professionals should be trained in smoking cessation techniques, while it was $73.9 \%$ among non smokers $\left(X^{2}=43.784, P=0.084\right)$.

\subsection{Relationship of Different Variables with Smoking of Cigarette among Health Workers}

Table 8 illustrates that $7.6 \%$ of physicians, nurses $4 \%$, and pharmacists $11.1 \%$ are smokers $\left(X^{2}=41.467, P=\right.$ 0.000). Among physicians, interns $11.3 \%$, medical officers/residents $4.1 \%$, consultants $4.8 \%$ and no professor are smokers $\left(\mathrm{X}^{2}=8.729, \mathrm{P}=0.033\right) .10 \%$ of males smoke while it was $2.4 \%$ among females $\left(\mathrm{X}^{2}=3.736, \mathrm{P}=\right.$ 0.053). No health worker less than 20 years smoke, while $6.4 \%$ and $7.1 \%$ age groups $20-40$ and above 40 years smoke respectively $\left(X^{2}=0.813, P=0.666\right) .10 .9 \%$ of those that are single smoke, while $10 \%, 9.4 \%$ and $3 \%$ among divorced, widowed, and married health professionals smoke $\left(X^{2}=26.618, P=0.000\right)$.

\section{Discussion}

Our study has shown that the overall life prevalence of cigarette smoking among health workers in Enugu was $21.1 \%$, while currently smoking prevalence was $6.5 \%$. This result in our study is lower than study done among primary health care (PHC) workers in Abu Dhabi, but lower than studies done in Jordan 65\%, and Saudi Arabia 45\% [19] [29] [30]. It is surprising that overall life prevalence 31.7\% and currently smoking prevalence $7.6 \%$ was significantly higher among physicians who are supposed to be leaders in the medical team than other health workers. However, prevalence of smoking among physicians in this study is similar to studies done in UAE and Kuwait where 33.6\% and 31\% were found respectively [19] [26] [27]. The findings in the studies done in Japan, Bahrain, Saudi Arabia, Qatar, and Oman, with rates of 29.4\%, 23\%, $14.2 \%, 12 \%$, and $11 \%$ were less than in our study [26]-[28].

The prevalence of smoking among male health workers is higher than females in this study. This is similar to the studies done in some countries [29]-[31], but different from the study done in Abu Dhabi where there were no differences in terms of age, gender, occupation and ethnicity [19]. Though, the smoking prevalence in this 
Table 8. Relationship of different variables with smoking of cigarette.

\begin{tabular}{|c|c|c|c|c|c|c|}
\hline Variables & Category & $\begin{array}{l}\text { Smoker } \\
\mathrm{N} \%\end{array}$ & Non-smoker & Total & $\begin{array}{c}\text { Chisquare } \\
\mathrm{X}^{2}\end{array}$ & $\begin{array}{l}\text { P-value } \\
\text { P }\end{array}$ \\
\hline \multirow{4}{*}{ Category of health workers } & Physicians & $11(7.6)$ & $134(92.4)$ & 145 & \multirow{4}{*}{41.467} & \multirow{4}{*}{0.000} \\
\hline & Nurses & $4(4.0)$ & $97(96.0)$ & 101 & & \\
\hline & Pharmacists & 3 (11.1) & 24 (88.9) & 27 & & \\
\hline & Others & $6(6.3)$ & 90 (93.7) & 96 & & \\
\hline \multirow{4}{*}{$\begin{array}{l}\text { Professional Hierarchy of } \\
\text { Physicians }\end{array}$} & Interns & $8(11.3)$ & $63(88.7)$ & 71 & \multirow{4}{*}{8.729} & \multirow{4}{*}{0.033} \\
\hline & Medical officers/Residents & $2(4.1)$ & 47 (95.9) & 49 & & \\
\hline & Consultants & $1(4.8)$ & $20(95.2)$ & 21 & & \\
\hline & Professors & $0(0)$ & $4(100)$ & 4 & & \\
\hline \multirow{2}{*}{ Sex } & Male & $20(10.0)$ & $180(90.0)$ & 200 & \multirow{2}{*}{3.736} & \multirow{2}{*}{0.053} \\
\hline & Female & $4(2.4)$ & $165(97.6)$ & 169 & & \\
\hline \multirow{3}{*}{ Age (Years) } & $<20$ & $0(0)$ & $4(100)$ & 4 & \multirow{3}{*}{0.813} & \multirow{3}{*}{0.666} \\
\hline & $20-40$ & $18(6.4)$ & $262(93.6)$ & 280 & & \\
\hline & $>40$ & $6(7.1)$ & 79 (92.9) & 85 & & \\
\hline \multirow{4}{*}{ Marital Status } & Single & 13 (10.9) & $106(89.1)$ & 119 & \multirow{4}{*}{26.618} & \multirow{4}{*}{0.000} \\
\hline & Married & $6(3.0)$ & $193(97.0)$ & 198 & & \\
\hline & Divorced & $2(10.0)$ & $18(90.0)$ & 20 & & \\
\hline & Widowed & $3(9.4)$ & 29 (90.6) & 32 & & \\
\hline
\end{tabular}

study among married people was not as high as in some studies [19] [27] [31], but 3\% found can have influence on smoking initiation among children and other family members, and also harmful health effects. Our study also revealed that health care workers who are single $10.9 \%$ smoke more significantly than others who are married, divorced, or widowed. This could be that the majority of interns that smoke are not married and younger in the profession.

Among the physicians in our study, the prevalence of smoking among interns was the highest $11.3 \%$, while it was $4.8 \%$ among consultants and no professor was smoking. Generally, the prevalent rate of currently smoking among health workers $6.5 \%$ is lower than that of Nigerian adult population where $7.3 \%$ was reported [32].

All health workers knew that cigarette smoking is hazardous to health, with $79.4 \%$ of them believed that it could cause lung cancer. The findings in this study which is showing a gap between knowledge and practice is similar to some studies done in Nigeria, Oman, Jordan, and Saudi Arabia [9] [27]-[31]. Also, our study revealed that majority of health workers $90.8 \%$ smoked between 1 - 5 sticks per day, which is considered to be light/ moderate. Past studies have reported that light/moderate smokers are more willing to quit smoking than heavy smokers if smoking cessation intervention programmes are instituted [33], so the number of health workers smoking may decrease with effective cigarette smoking cessation intervention programmes. The intervention programmes will be very important because it has been reported that physicians advice may cause reduction or eliminate smoking in $10 \%$ - 25\% of patients that were conselled [17] [34]. The health workers who are supposed to be role models for their patients need to stop smoking to be able to achieve maximum results.

The findings in our study revealed that majority of health workers quitted smoking because of their profession $33.3 \%$, while $22.2 \%$ was because of the knowledge of health hazards. There is need to let health workers know that the general public and their patients in particular see them as role models, and one of the most effective behaviour interventions is advice from a health care professional.

Majority of smokers $89.7 \%$ in this study agreed that smoking should be banned in all health facilities. This is in agreement with what was recommended in the physician's role in smoking cessation where it was stated that 
hospital should enforce non smoking rule, and also the employees within it should be non-smoking examplars [34]. More non smokers among health care workers $68 \%$ significantly agreed that cigarettes sales should be banned, while $69.2 \%$ of smokers said that advertisement of cigarettes should be banned. There is no enforcement despite the Tobacco smoking decree promulgated in Nigeria which restricts smoking in certain public places, and also prohibits any form of tobacco advertisement. It is interesting from our study that $78.2 \%$ of smokers agreed that health care professionals should have a role in giving advice or information about smoking cessation to patients. The findings show that many of the smokers will be ready to quit smoking if for the benefits for patients. More non smokers $97.3 \%$ than smokers 58.9\% agreed that all health care providers should not smoked.

\section{Conclusion}

The smoking prevalence among health workers is high in this study, and it is believed that the smoking status influences their approach to the smoking problems of their patients. It is suggested that health promotion programmes concerning smoking in particular should be introduced among health care workers for the benefits of themselves and their patients.

\section{Acknowledgements}

The authors would like to show appreciation to all health workers who participated in this study. We thank Asemota Osamienmwenfan, Akatakpo Omonigho, and Umeadi Anthony that collected the data for their commitment.

\section{Conflict of Interests}

The authors declare that there is no conflict of interests regarding the publication of this paper.

\section{References}

[1] World Health Organization (2013) Report on the Globl Tobacco Epidemic. Enforcing Bans on Tobacco Advertising, Geneva.

[2] Derek, R.S. and Peter, A.L. (2011) Smoking among Healthcare Professionals. Darlington Press, 12-17.

[3] Wipfli, H. and Samset, J.M. (2009) Global Economic and Health Benefits of Tobacco Control: Part 1. Clinical Pharmacology \& Therapeutics, 263-271. http://dx.doi.org/10.1038/clpt.2009.93

[4] WHO (2002) Reducing Risks and Promoting Healthy Life. World Health Organization, Geneva.

[5] World Bank (1999) Global Trends in Tobacco Use. Curbing the Epidemic: Governments and Economics of Tobacco Control. World Bank, New York, 3.

[6] Guidon, G. and Boisclair, D. (2003) Past, Current and Future Trends in Tobacco Use. The World Bank, Washington DC.

[7] Bartecchi, C.E., Mackenzie, T.D. and Schrier, R.W. (1995) The Global Tobacco Epidemic. Scientific American Journal, 272, 44-51. http://dx.doi.org/10.1038/scientificamerican0595-44

[8] Fawibe, A.E. and Shittu, A.O. (2011) Prevalence and Characteristics of Cigarette Smokers among Undergratuates of University of Ilorin, Nigeria. Nigerian Journal of Clinical Practice, 14, 201-205. http://dx.doi.org/10.4103/1119-3077.84016

[9] Owonaro, P.A. and Eniojukan, J.F. (2015) Cigarette Smoking Practices, Perceptions and Awareness of Government Policies among Pharmacy Students in Niger Delta University in South-South, Nigeria. UK Journal of Pharmaceutical and Biosciences, 3, 20-29. http://dx.doi.org/10.20510/ukjpb/3/i5/89484

[10] Josseran, L., King, G., Guilbert, P., Davis, J. and Brucker, G. (2005) Smoking by French General Practitioners: Behaviour, Attitudes and Practice. European Journal of Public Health, 15, 33-38. http://dx.doi.org/10.1093/eurpub/cki108

[11] Josseran, L., King, G., Velter, A., Dressen, C. and Grizeau, D. (2000) Smoking Behavior and Opinions of French General Practitioners. Journal of the National Medical Association, 92, 382-390.

[12] La Vecchia, C., Scarpino, V., Malvezzi, I. and Baldi, G. (2000) A Survey of Smoking among Italian Doctors. Journal of Epidemiology \& Community Health, 54, 320. http://dx.doi.org/10.1136/jech.54.4.320a

[13] Nardini, S., Bertoletti, R., Rastelli, V. and Donner, C.F. (1998) The Influence of Personal Tobacco Smoking on the 
Clinical Practice of Italian Chest Physicians. European Respiratory Journal, 12, 1450-1453. http://dx.doi.org/10.1183/09031936.98.12061450

[14] Kawane, H. (2001) Smoking among Japanese Physicians. JAMA, 286, 917. http://dx.doi.org/10.1001/jama.286.8.917-JLT0822-3-1

[15] Kawane, H. (1993) Prevalence of Smoking among Physicians in Japan. American Journal of Public Health, 83, 1640. http://dx.doi.org/10.2105/AJPH.83.11.1640

[16] Ronald, M.D. (1993) When Doctors Smoke. Tobacco Control, 2, 187-188. http://dx.doi.org/10.1136/tc.2.3.187

[17] Centres for Disease Control and Prevention (CDC) (2001) Physician and Other Health-Care Professional Counselling of Smokers to Quit-United States 1991. http://www.cdc.gov/

[18] Richmond, R.L. (1999) Physicians Can Make a Difference with Smokers: Evidence-Based Clinical Approaches. The International Journal of Tuberculosis and Lung Disease, 3, 100-112.

[19] Salama, A.H., Maryam, A.A. and Khadija, A.M. (2015) Smoking Prevalence, Attitudes and Behaviours of Primary Healthcare Providers and Its Impact on Their Smoking Cessation Counselling Practices. Ibnosina Journal of Medicine and Biomedical Sciences, 7, 47-55.

[20] Fiore, M.C., Pierce, J.P., Remington, P.L. and Fiore, B.J. (1990) Cigarette Smoking: The Clinician’s Role in Cessation, Prevention, and Public Health. Disease-A-Month, 36, 181-242. http://dx.doi.org/10.1016/0011-5029(90)90007-e

[21] Wong-McCarthy, W.J. and Gritz, E.R. (1982) Preventing Regular Teenage Cigarette Smoking. Paediatric Annals, 11, 638-689. http://dx.doi.org/10.3928/0090-4481-19820801-09

[22] Lancaster, T., Stead, L., Silagy, C. and Sowden, A. (2000) Effectiveness of Interventions to Help People Stop Smoking: Findings from the Cochrane Library. BMJ, 321, 355-358. http://dx.doi.org/10.1136/bmj.321.7257.355

[23] WHO (2001) Encouraging Stopping Smoking. World Health Organization, Geneva.

[24] World Health Organization (2014) Tobacco Free Initiative. WHO. http://www.who.int/

[25] Holford, T.R., Meza, R., Warner, K.E., Meernik, C., Jeon, J., Moolgavkar, S.H. and Levy, D.T. (2014) Tobacco Control and the Reduction in Smoking-Related Premature Deaths in the United States, 1964-2012. JAMA, 311, 164-171. http://dx.doi.org/10.1001/jama.2013.285112

[26] Bener, A., Gomes, J., Anderson, J.A. and Abdullah, S. (1994) Smoking among Health Professionals. Medical Education, 28, 151-157. http://dx.doi.org/10.1111/j.1365-2923.1994.tb02536.x

[27] Al-Lawati, J.A., Nooyi, S.C. and Al-Lawati, A.M. (2009) Knowledge, Attitudes and Prevalence of Tobacco Use among Physicians and Dentists in Oman. Annals of Saudi Medicine, 29, 128-133. http://dx.doi.org/10.4103/0256-4947.51803

[28] Hiroshi, K. and Rinzo, S. (1996) Smoking among Doctors in a Medical School Hospital. Kawasaki Medical Journal, 22, 211-216.

[29] El khushman, H.M., Sharara, A.M., Al-Laham, Y.M. and Hijazi, M.A. (2008) Cigarette Smoking among Health Care Workers at King Hussein Medical Center. Journal of Hospital Medicine, 3, 281-284. http://dx.doi.org/10.1002/jhm.319

[30] Siddique, S. and Ogbeide, D.O. (2001) Profile of Smoking Health Staff in a Primary Care Unit at a General Hospital in Riyadh Saudi Arabia. Saudi Medical Journal, 22, 1101-1104.

[31] Okeke, T.A. (2004) Smoking Habits of Physicians in Enugu, Nigeria. Journal of Community Medicine and Primary Health Care, 16, 34-38.

[32] World Health Organization (2012) Global Adult Tobacco Survey, Nigeria.

[33] COMMIT Research Group (1995) Community Intervention Trial for Smoking Cessation (COMMIT): I. Cohort Results from a Four-Year Community Intervention. American Journal of Public Health, 85, 183-192. http://dx.doi.org/10.2105/AJPH.85.2.183

[34] Louise, M.N. (1990) The Physician’s Role in Smoking Cessation, A Present and Future Agenda. Chest, 97, $28-29$. http://publications.chestnet.org/ 


\section{Submit or recommend next manuscript to SCIRP and we will provide best service for you:}

Accepting pre-submission inquiries through Email, Facebook, LinkedIn, Twitter, etc.

A wide selection of journals (inclusive of 9 subjects, more than 200 journals)

Providing 24-hour high-quality service

User-friendly online submission system

Fair and swift peer-review system

Efficient typesetting and proofreading procedure

Display of the result of downloads and visits, as well as the number of cited articles

Maximum dissemination of your research work

Submit your manuscript at: http://papersubmission.scirp.org/ 